\title{
Physical and sexual aggression against elderly persons reported in the city of São Paulo
}

\section{Abstract}

Objectives: To characterize the population of elderly people who have suffered physical and sexual violence, and describe the features of this aggression based on the Information System for Violence and Injury Surveillance (ISVIS) of the Municipal Health Department of the city of São Paulo. Method: A cross-sectional, retrospective study was performed of all cases of elderly victims of physical and sexual violence reported in São Paulo in 2013. Results: A total of 602 cases of elderly victims of physical abuse were reported, of which $52.3 \%$ were male. In the same period there were ten reported cases of elderly victims of sexual assault, $90 \%$ of whom were female. The main diagnosis of injury was head trauma $(33.2 \%)$ and $65.0 \%$ of victims were discharged from hospital immediately. abuse; Information Systems. Conclusion: Physical abuse with the use of physical force was higher among male elderly persons, and sexual assault was higher among women. Most of the attacks took place at the residence of the elderly person, and were committed by family members.

Cintia Leci Rodrigues ${ }^{1}$ Jane de Eston Armond? Carlos Gorios ${ }^{2}$

\footnotetext{
1 Universidade de Santo Amaro, Núcleo de Saúde Coletiva e Mental. São Paulo, SP, Brasil

2 Universidade de Santo Amaro, Núcleo de Cirurgia. São Paulo, SP, Brasil. 


\section{INTRODUCTION}

Population aging, which has occurred most significantly in developing countries such as Brazil, its implications for government policy, and related demographic studies, have increased significantly in recent years. ${ }^{1,2}$ Older people are the most significant users of health services, and data has suggested that such use has increased in recent years. ${ }^{3}$ In Brazil, studies of morbidities caused by violence among the elderly are recent.

The social implications of population aging for public health are a major concern as, unlike in developed countries where the increase in life expectancy was gradual and occurred in tandem with higher technological and scientific development, making it possible to provide a better quality of life and health for this portion of the population, in developing countries the transition has been more abrupt, resulting in a lack of preparation for the care of this population group. ${ }^{4}$

One of the most troubling reasons for elderly individuals seeking health services is the high incidence of violence suffered by this group, representing a social phenomenon based on the actions of individuals or groups that cause physical damage, emotional and moral to others. ${ }^{5}$

Today, national and international studies consider the family environment as the primary context for incidents of violence against the elderly, representing a serious social and public health problem. $^{6-8}$

The scarcity of information regarding the victims and aggressors is a delicate issue, as elderly individuals, in general, do not report suffering physical and sexual abuse, because of embarrassment and the fear of punishment by their aggressors, who are often their caregivers. Dealing with domestic violence against the elderly, inside or outside the home environment, involves training health services how to address and resolve this issue.

While literature reports other forms of violence against the elderly, this study addresses two types: Physical Violence, namely the use of physical force that can produce an injury, wound, pain, disability or death, and Sexual Violence, heterosexual and homosexual acts or sexual activity which aims to stimulate the victim or use him or her for sexual arousal and erotic and sexual practices imposed by means of grooming, physical violence and threats. ${ }^{10,11}$

The use of data collected by public sector health information systems in the analysis of the health situation of an individual and the impact of interventions has grown in recent years. ${ }^{12}$ The implementation of the Sistema de Informação para a Vigilância de Violências e Acidentes ("Information System for Violence and Injury Surveillance”) (SIVVA) by the São Paulo municipal health network has enabled the gathering of information for the diagnosis, planning, monitoring and evaluation of actions against the violence and accidents. ${ }^{13}$

In 2013 the projection of the elderly population in the city of São Paulo was 1,470,719 inhabitants, of whom $59.8 \%$ were women. ${ }^{14}$ That same year $\mathrm{R} \$ 30,058,110.88$ was spent treating morbidities caused by external causes (accidents and violence) among the elderly, as reported by the Sistema de Informação Hospitalar ("Hospital Information System”). ${ }^{15}$

In this context, the availability of information about the characteristics of violence against the elderly can assist in the debate regarding strategies to deal with this problem from a health service perspective. $^{16}$

The present study aimed to characterize the elderly population who suffered physical and sexual violence in the city of São Paulo in 2013 and to describe the characteristics of this aggression based on information available from SIVVA.

\section{METHOD}

A cross-sectional, quantitative, descriptive, retrospective study was performed. All 612 men and women aged 60 years or older who were victims of cases of physical and sexual violence that were registered with the Information System for Violence 
and Injury Surveillance (SIVVA) of the Secretaria Municipal de Saúde (Municipal Health Department) of São Paulo were included in the study. This includes all reported suspected and confirmed cases of accidents and violence, ${ }^{17}$ in São Paulo in the period from January to December 2013.

The variables used for the study were: age (years), gender, type of violence (physical and sexual), frequency of violence, the relationship between the aggressor and the victim (family and other acquaintances, strangers), diagnosis of injury, outcome of case (referral to social services, release from hospital, hospitalization, death during treatment or dead on arrival), location of violence (home, public thoroughfares, Long Term Care Institutions), disability (physical, mental, visual) and time of aggression (day or night).

All variables were based on public domain data available from the SIVVA system of the Secretaria Municipal de Saúde of São Paulo.

The information available on SIVVA depends on health professionals notifying the system of victims treated for violence/accidents. Such notification takes the form of a specific instrument (a notification record for each case of confirmed violence or accidents).

Thus, the SIVVA database is not representative of all accidents or violence, but only cases that are registered with the health services.

The variables of interest were collected in the database and tabulated. Descriptive analysis was then performed for characterization of the sample by calculating the absolute and relative frequencies.

As recommended by the Conselho Nacional de Saúde ("National Health Council") (CNS) 466/12, the authors did not seek the approval of the Ethics Committee of the University, as secondary data in the public domain database was used.

\section{RESULTS}

In 2013 in São Paulo 602 cases of physical abuse involving elderly persons were registered.
Of elderly victims of physical and sexual violence $40.2 \%$ were aged between 60 and 64 years; $23.1 \%$ were aged between 65 and 69 years and $36.7 \%$ were aged over 70 years. In terms of the gender of the victim and the type of violence, $52.3 \%$ of victims of reported cases of physical assaults were male and $47.7 \%$ were female (602 cases). In the same period, there were ten reports of elderly victims of sexual assault, of whom $90 \%$ were female and $70 \%$ were under the age of 70

The type of aggression was described as physical aggression $(70.3 \%)$ or sexual assault (50.0\%). In terms of frequency of aggression, $36.4 \%$ of victims reported that it was the first time they had been physically or sexually assaulted while $21.4 \%$ said they had suffered physical or sexual aggression more than once.

With regard to the relationship between the aggressor and the victim, in cases of physical aggression $58.5 \%$ of the aggressors were relatives or other acquaintances, while $36.4 \%$ were male and aged between 35 and 39 years. The characterization of the aggressor was similar in cases of sexual assault - a male family member aged between 20 and 24 years. Injuries were diagnosed as head trauma (S00-S09) 33.2\%; injuries involving multiple body regions (T00-T07) 10.1\%; and injuries to unspecified location of torso, limb or body region (T08-T14) (10.0\%).

Regarding the outcome of cases, $65.0 \%$ were discharged immediately, and less than $1 \%$ of cases of violence (physical or sexual) against the elderly ended in death, either during treatment at the health care center or at a later date.

In terms of location, $47.2 \%$ of physical or sexual assaults took place in the residence of the elderly victim. With respect to physical violence, 11.1\% occurred in public thoroughfares.

Of elderly individuals who suffered physical and/or sexual assault, 1.8\% had some form of disability, whether physical, mental or visual.

All the physical and sexual assaults on the elderly occurred during the day. 


\section{DISCUSSION}

The question of assaults against the elderly has led to a discussion aimed at the agents involved in violence/aggression against this age group: the victims of violence, aggressors and caregivers, highlighting the political, economic, anthropological, biological, cultural, and psychological factors linked to social aging and violence. $^{18}$

The present study found significant differences in the epidemiological profile of the assaults on the elderly according to gender, allowing aspects related to the victim, the event itself and the aggressor to be analyzed in more detail. ${ }^{19}$ Reported cases of physical aggression were higher among males and sexual assaults more frequent among females. Both types of aggression were more common among elderly persons aged under 70 years, within the residence of the elderly individual, and committed by a family member and/or someone known to the elderly victim.

The study identified the residence of the elderly person as the main location for the occurrence of the violent event, whether physical aggression or a sexual assault. One of the arguments found in literature which may explain the higher frequency of situations of aggression in the home, among both elderly men and women, is the conflict between the generations, permeated by disputes over physical space and the financial difficulties of the family. ${ }^{19,20}$

In both genders, the most vulnerable elderly persons are physically or mentally dependent, especially when they have cognitive deficits, sleep disorders, incontinence, or walking difficulties, and thus require intensive care in their activities of daily living. ${ }^{21}$ In the present study, $1.8 \%$ of elderly persons who suffered physical and/or sexual assault had some form of disability, whether physical, mental or visual. The probable under-reporting of abuse and the inadequate completion of case report records by health professionals with respect to suspected and/or confirmed accidents should also be mentioned. Physical force was the most common means of aggression used in assaults on both genders, corroborating findings from other studies. $^{19}$

Regarding the frequency of aggression, in $36.4 \%$ of reported cases, whether physical or sexual, the victim said it was a first time attack. However, in this case, it is not clear whether it was the attack that occurred for the first time or if it was the first time an attack had been reported.

Aggression against the elderly is a recently reported phenomenon in Brazil and many other countries. The theme has been described in scientific journals as "beating up grandparents". 22,23 In Brazil, description of the characteristics of the cases of violence and accidents occurring in the country was previously limited to the information provided by the Sistema de Informação sobre Mortalidade ("Mortality Information System") (SIM) and the Sistema de Informação de Internação Hospitalar do Sistema Único de Saúde ("Hospital Admission Information System of the National Health System") (SIH/SUS). The range of variables included in the monitoring of these events expanded in 2006, with the implementation of the Sistema de Vigilância de Violências e Acidentes ("Violence and Injury Surveillance System") (Viva). ${ }^{24}$

In São Paulo, the Information System for Violence and Injury Surveillance (SIVVA) was implemented in 2008. The SIVVA database, however, is not representative of all cases of abuse against the elderly, but only cases which are registered with the health services, and is aimed at showing a profile of attacks in São Paulo.

Currently, in the area of health, the use of hard data to analyze, plan and make decisions pertinent to the health conditions of a particular region is recommended. To do this, information systems are seen as essential tools for managing government policy. ${ }^{25}$ Dialogue between all these agencies and institutions is essential to guarantee the rights of the elderly and ensure the inclusion in budgets of the necessary resources to meet their needs. 
One limitation of the present study was the difficulty of obtaining accurate information regarding the issue of violence, due to the underreporting of cases. Data of cases of physical and sexual violence that do not reach the health services is not collected, and so is not input into the SIVVA database.

\section{CONCLUSION}

Physical abuse was higher among male elderly individuals $(52.3 \%)$ in the 60 to 64 years old age group. It was most frequently committed by a family member and/or acquaintance of the victims

\section{REFERENCES}

1. Veras R. Envelhecimento populacional contemporâneo: demandas, desafios e inovações. Rev Saúde Pública 2009;43(3):548-54.

2. Telles JL, Borges APA. Velhice e saúde na região da África Subsaariana: uma agenda urgente para a cooperação internacional. Ciênc Saúde Coletiva 2013; 18(12):3553-62.

3. Paskulin LMG, Valer DB, Vianna LAC. Utilização e acesso de idosos a serviços de atenção básica em Porto Alegre (RS, Brasil). Ciênc Saúde Coletiva 2011;16(6):2935-44.

4. De Lorenzi DRS, Catan LB, Moreira K, Ártico GR. Assistência à mulher climatérica: novos paradigmas. Rev Bras Enferm 2009;62(2):287-93.

5. Minayo MCS. Violência contra idosos: relevância para um velho problema. Cad Saúde Pública 2003;19(3):783-91.

6. Wanderbroocke ACNS, Moré CLOO. Abordagem profissional da violência familiar contra o idoso em uma unidade básica de saúde. Cad Saúde Pública 2013;29(12):2513-22.

7. Abath MB, Leal MCC, Melo Filho DA. Fatores associados à violência doméstica contra a pessoa idosa. Rev Bras Geriatr Gerontol 2012;15(2):305-14.

8. Gonçalves JRL, Silva LC, Soares PPB, Ferreira PCS, Zuffi FB, Ferreira LA. Perception and conduct of health professionals about domestic violence against the elderly. Rev Pesqui Cuid Fundam 2014;6(1):194-202. using physical force. Sexual abuse predominated among women.

Most of these assaults (sexual and physical) took place at the residence of the elderly individual. According to SIVVA data, the main diagnosis was head trauma and $65.0 \%$ of cases were discharged immediately.

The training of health professionals to meet the needs of the elderly, including preparing them to identify, monitor and refer the patient who has suffered the aggression, is vital. Assistance organized through a multidisciplinary and intersectoral care network can be a strategy for the protection of vulnerable elderly persons.

9. Shimbo AY, Labronici LM, Mantovani MF. Reconhecimento da violência intrafamiliar contra idosos pela da Estratégia Saúde da Família. Esc Anna Nery Rev Enferm 2011;15(3):506-10.

10. Oliveira MLC, Gomes ACG, Amaral COM, Santos LB. Características dos idosos vítimas de violência doméstica no Distrito Federal. Rev Bras Geriatr Gerontol 2012;15(3):555-66.

11. Sousa DJ, White HJ, Soares LM, Nicolosi GT, Cintra FA, D'Elboux MJ. Maus-tratos contra idoso: atualização dos estudos brasileiros. Rev Bras Geriatr Gerontol 2010;13(2):321-28.

12. Tomimatsu MFAI, Andrade SM, Soares DA, Mathias TAF, Sapata MPM, Soares DFPP, et al. Qualidade da informação sobre causas externas no Sistema de Informações Hospitalares. Rev Saúde Pública 2009;43(3):413-20.

13. São Paulo. Coordenação de Vigilância em Saúde. Sistema de Informação para a Vigilância de Violências e Acidentes - SIVVA: manual de preenchimento ficha de notificação de casos suspeitos ou confirmados. São Paulo: Secretaria Municipal de Saúde; 2007.

14. Fundação Sistema Estadual de Análise de Dados [Internet]. São Paulo: Prefeitura de São Paulo; 2013- . Perfil Municipal [acesso em 20 jun. 2014];. Disponível em: http://www.imp.seade.gov.br/frontend/\#/

15. Ministério da Saúde. DATASUS. Sistema de Informação Hospitalar - SIH [Internet]. Rio de Janeiro: DATASUS; 2008 [acesso em 20 jul. 2014]. Disponível em: http://www.prefeitura.sp.gov.br 
16. Facuri CO, Fernandes AMS, Oliveira KD, Andrade TS, Azevedo RCS. Violência sexual: estudo descritivo sobre as vítimas e o atendimento em um serviço universitário de referência no Estado de São Paulo, Brasil. Cad Saúde Pública 2013;29(5):889-98.

17. São Paulo. Secretaria Municipal de Saúde. Sistema de Informação e Vigilância de Violências e Acidentes SIVVA [Internet]. São Paulo: Prefeitura de São Paulo; 2013 [acesso em 28 ago. 2014]. Disponível em: http:// www.prefeitura.sp.gov.br.

18. Castro AP, Guilam MCR, Sousa ESS, Marcondes WB. Violência na velhice: abordagens em periódicos nacionais indexados. Ciênc Saúde Coletiva 2013;18(5):1283-92.

19. Mascarenhas MDM, Andrade SSCA, Neves ACM, Pedrosa AMG, Silva MMA, Malta DC. Violência contra a pessoa idosa: análise das notificações realizadas no setor saúde - Brasil, 2010. Ciênc Saúde Coletiva 2012;17(9): 2331-41.

20. Moraes CL, Apratto Junior PC, Reichenheim ME. Rompendo o silêncio e suas barreiras: um inquérito domiciliar sobre a violência doméstica contra idosos em área de abrangência do Programa Médico de
Família de Niterói, Rio de Janeiro, Brasil. Cad Saúde Pública 2008;24(10):2289-2300.

21. Sousa DJ, White HJ, Soares LM, Nicolosi GT, Cintra FA, D'Elboux MJ. Maus tratos contra idosos: atualização dos estudos brasileiros. Rev Bras Geriatr Gerontol 2010;13(2):321-8.

22. Brasil. Presidência da República, Subsecretaria de Direitos Humanos. Plano de ação para o enfrentamento da violência contra a pessoa idosa. Brasília, DF; Secretaria Especial dos Direitos Humanos; 2005.

23. São Paulo (Cidade). Secretaria da Saúde. Violência doméstica contra a pessoa idosa: orientações gerais. São Paulo: CODEPPS; 2007.

24. Brasil. Ministério da Saúde. Viva: instrutivo de notificação de violência doméstica, sexual e outras violências. Brasília, DF: Ministério da Saúde; 2011.

25. Kind L, Orsini MLP, Nepomuceno V, Gonçalves L, Souza GA, Ferreira MFF. Subnotificação e (in)visibilidade da violência contra mulheres na atenção primária à saúde. Cad Saúde Pública 2013;29(9):1805-15. 